\title{
高温・高圧水によって分別回収された アスファルト混合物骨材の性状と品質について
}

\author{
秋葉正 $-{ }^{1} \cdot$ 加納陽輔 ${ }^{2} \cdot$ 栗谷川裕造 ${ }^{3}$ \\ ${ }^{1}$ 正会員 博 (工) 日本大学生産工学部土木工学科 (₹ 275-8575 千葉県習志野市泉町一丁目 2-1) \\ ${ }^{2}$ 正会員＼cjkstart博(工) 日本大学生産工学部土木工学科 ( 275-8575 千葉県習志野市泉町一丁目 2-1) \\ ${ }^{3}$ 正会員＼cjkstart博(工) 日本大学生産工学部土木工学科（广 275-8575 千葉県習志野市泉町一丁目 2-1)
}

90 年代後半より普及した排水性アスファルト混合物は, 供用後 , 間もなく 10 年を経過するものも多く, 今後, 良質な 骨材やポリマー改質アスファルトを含有した排水性舖装発生材が大幅に増加するものと考えられる 現行の舗装リサイク ルシステムは, 骨材配合やアスファルト性状の異なる舗装発生材を一樣に破砕・分級し, 効率的に再生骨材を製造するこ とで舗装材料の再資源化の促進に寄与してきた .しかしながら，昨今における舗装材料の多樣化と機能化を背景に再生骨 材の需給や品質管理は一層複雑化する傾向にあり, 再生用添加剂によるポーラスアスファルト混合物への再利用をはじめ, 持続的な循環利用が困難な現況にある.本研究では,多くのリサイクルシステムが分別回収を基盤に合理化したことを踏 まえて, 高温・高圧水による舗装発生材の分別プロセスを提案し, 繰返し分別回収された骨材の性状と品質を評価した .

Key Words : high-temperature and high-pressure water ,reclaimed asphalt pavement, recycle, reclaimed material

\section{1 .はじめに}

近年 , 道路舗装の分野は高度成長期以降の膨大なス卜 ックと環境保全に対する社会的二ーズを抱え，本格的な メンテナンスおよびリサイクルの時代を迎えている .メ ンテナンスの際には, 既設舗装材の処理を余儀なくされ るが, 再生アスファルト混合物（以下，再生材）の老朽 化やポリマー改質アスファルトの普及を背景に , アスフ アルト舗装発生材 (以下, 舗装発生材) の品質は益々多 樣化する傾向にある.いずれにしても，舗装発生材は鉱 物資源である骨材と石油資源であるアスファルトによっ て構成された貴重な天然資源混合物であり，資源の消費 抑制や環境保全の観点からも，より有効かつ持続的な利 用を推進していかなければならない1).

現行の舗装リサイクルシステムは, 集積された多樣な 発生材を一樣に破砕・分級し, 効率的に再生骨材を製造 することで, 舗装発生材のリサイクル促進に寄与してき た ${ }^{1)}$.しかしながら，現行の機械破砕方式で避けること のできない骨材構造の不規則な変化や旧アスファルトの 偏在など, 再材料化と同時に含有骨材の舗装材料として の品質を損耗させていると言える ${ }^{2), 3)}$. また , 再生骨材を 再び表層用加熱アスファルト混合物用骨材として用いる 際は, 残存する旧アスファルトの性状を再生用添加剂に よって回復させる手法が一般的であるが, 多樣化する舗
装発生材への有効性は不明確であり，生産性や施工性， 供用性等を確保するため, 再生混合物を構成する約 50〜 $70 \%$ の材料を新規の骨材およびアスファルトに依存する 傾向にある .このことは, 直接的な資源消費やコストア ップにもつながり, 再生骨材の需給か極めて流動的なこ とからも, 舗装発生材の大半力潞盤材等として利用され る現況にある.舗装発生材が含有する骨材の品質や，こ れらの枯渇問題に配慮すると, より付加価值の高い表層 材料としての循睘利用を推進していかなければならない . 今後も舗装材料の多樣化は, 再生骨材の管理と利用の体 系を一層複杂隹化させる恐れもあり，資源の有効利用や省 資源・省コス卜化を図るためにも，再材料化と同時に舗 装発生材中の骨材を資材の状態へと初期化することか不 可欠と考える ${ }^{4)(8)}$.

以上のことを踏まえて, 本研究では多くのリサイクル が分別回収を基盤として合理化されたことを踏まえて， 高温・高圧水を用いた舗装発生材の分別プロセスを提案 し, 加熱混合したアスファルト分と繰返し分別回収され た骨材の性状と品質を評価した .

\section{2 . 高温・高圧水による舗装発生材の分別回収}

超臨界水は, 水の臨界点である $273.9^{\circ} \mathrm{C} 、 22.1 \mathrm{MPa}$ を超 えた非凝縮性の流体であり, 光の密度は温度や圧力を操 


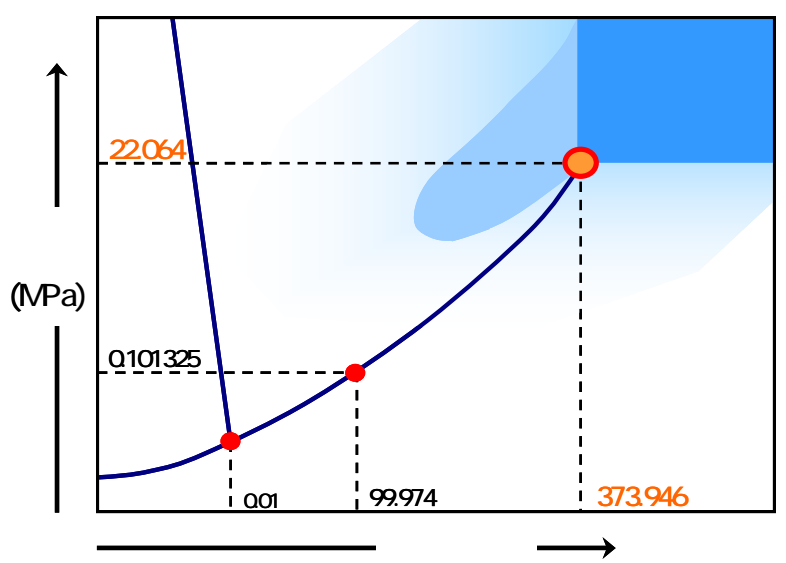

図 1 水の状態図
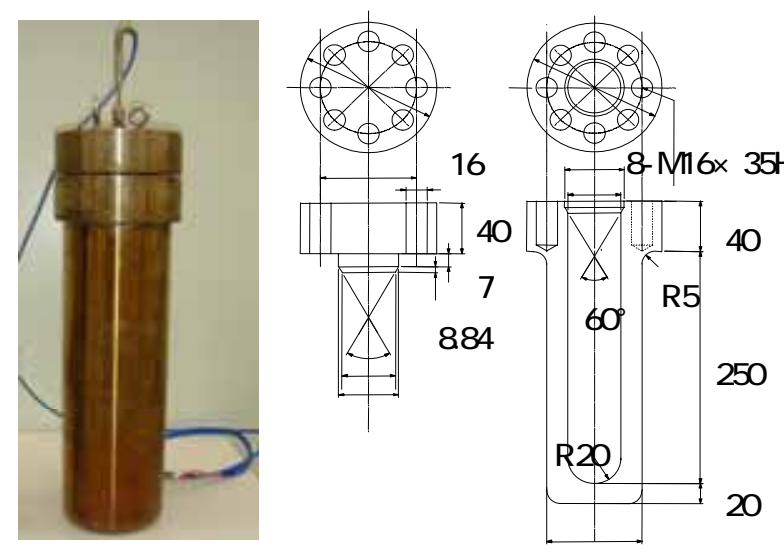

（a）超臨界試験用密閉容器

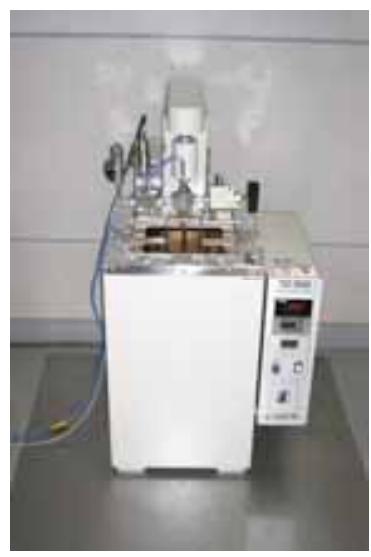

\begin{tabular}{|c|c|}
\hline 外形寸法 & $\begin{array}{l}\text { W550× D550x H850mm } \\
\text { (液槽部590+毘拌部260mm) }\end{array}$ \\
\hline 槽内寸法 & W200x D200x H450mm \\
\hline 温度範囲 & $-300 \sim+600^{\circ} \mathrm{C}$ \\
\hline 温度安定度 & $\pm 0.5^{\circ} \mathrm{C}$ \\
\hline 温度調節 & $\begin{array}{c}\text { デジタル式温度指示調節器 } \\
\text { PID制御方式 }\end{array}$ \\
\hline ヒーター & シースワイヤー式 $4 \mathrm{~kW}$ \\
\hline 摚拌機 & $\begin{array}{c}\text { 縦型摇拌方式 } \\
\text { スピードコトトールーター } \\
\text { 100W (タイマー付き) }\end{array}$ \\
\hline 定格電源 & AC200V 単相 $50 / 60 \mathrm{~Hz}$ \\
\hline 定格電流 & $1 \mathrm{~A}$ \\
\hline 重量 & 約 $81 \mathrm{~kg}$ \\
\hline
\end{tabular}

（b）超臨界試験用加熱槽

図-2 超臨界試験装置

作することで気体から液体相当まて連続的に変化する． このため, 密度の関数として表せる多くの溶媒物性や輸 送物性を精密に制御し, 目的に応じた溶媒性能を付与す ることが可能である.特に , 水は最も多樣な物質を溶か すことのできる液体であり，入手か容易なこと，安全性 や経済性に優れることから，本研究では亜臨界水および 超臨界水の溶媒物性に着目して, アスファルト混合物に 対する分離溶媒としての性能と適性を評価した .

水の状態図を図 1 に示す. 本研究て取り扱う亜臨界水

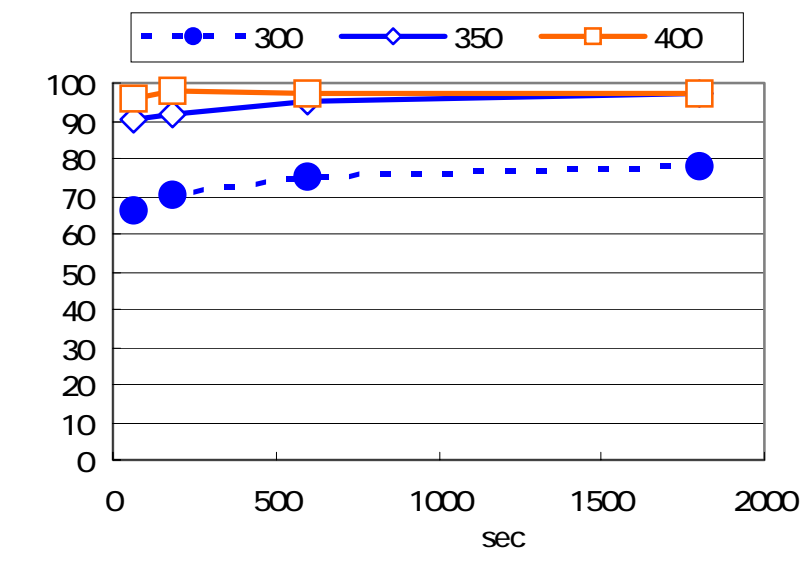

図-3 反応条件とアスファルト分離率の関係

は水の臨界点をやや下回る $350^{\circ} \mathrm{C} \cdot 16.5 \mathrm{MPa}$ の液相を指し ており，超臨界水については $400^{\circ} \mathrm{C} \cdot 25.0 \mathrm{MPa}$ の超臨界流 体を用いて分別実験を試みた．本実験で用いた超臨界試 験装置を図 2 に , アスファルト混合物の分別手順を以下 に述べる。

(1) 図-2(a) の超臨界試験用密閉容器 (約 $900 \mathrm{cc}$ ) に, 目 標圧力となる仕入量の水および共試体を投入する .

(2) 密閉容器を図 - 2(b) の加熱槽に沈めて, 容器内部が目 標とする温度と圧力に到達するまで加熱する．

(3) 所定時間 (180sec) 静置した後, 容器内部か常温・常 圧になるまで邻して内容物を回収する．

(4) 回収試料を濾過して残留分を炉乾燥し, アスファル 卜を被膜する前の骨材 (以下, 被膜前) とアスファ ルトを被膜した骨材 (以下, 被膜後), 分別回収され た骨材 (以下, 回収後) との乾燥質量の変化からア スファルト分離率を求める.

反応条件とストレートアスファルトに対する分離性能 の関係を図 3 に示す.亜臨界水, 超臨界水ともに , 180sec 前後の反応時間て供試体中の $90 \%$ 以上のアスファルトが 分離されているのが分かる . また, 既報の実験からスト レートアスファルトと改質アスファルト川型に関しては， これらの性状の差異が高温・高圧水の分離性能に大きく 影響することなく, 覀臨界水, 超臨界水の優れたアスフ アルト分離性能と骨材回収性能力確忍されている ${ }^{8) \sim 10)}$.

以上の結果を踏まえて本研究では, アスファルト舗装 発生材の分別再材料化に向けた基礎検討として, 亜臨界 水または超臨界水によって繰返し分別回収された骨材の 形質と材質，耐久性を評価した。また，これらを配合し たポーラスアスファルト混合物のカンタブロ試験および 圧裂試験から，舗装材料としての品質と再利用の可能性 について検討を行った 。

\section{3. 回収粗骨材に関する評価}

供試体は，アスファルトを被膜する前の新規の粗骨材 (6 号砕石: 栃木県産硬質砂岩) を基準として, 亜臨界水 $\left(350^{\circ} \mathrm{C} \cdot 16.5 \mathrm{MPa}\right)$ または超臨界水 $\left(400^{\circ} \mathrm{C} \cdot 25.0 \mathrm{MPa}\right)$ 

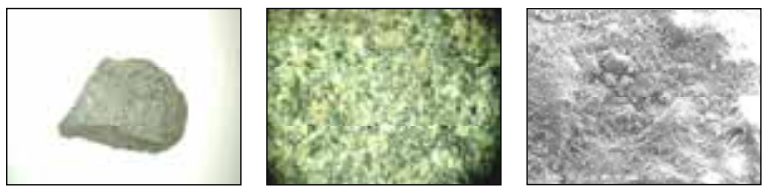

新規粗骨材 (2.5483g)
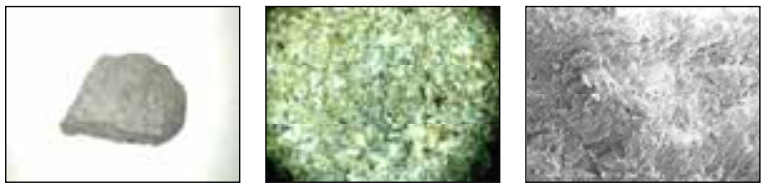

回収粗骨材 (2.5540g)

図 4 亜臨界水によって分別回収された粗骨材
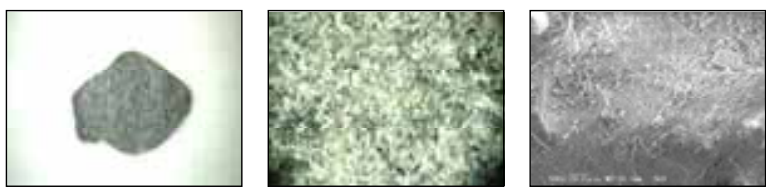

新規粗骨材 (2. 4551g)
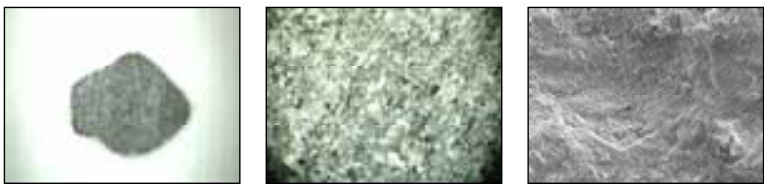

回収粗骨材 (2.4557g)

図 5 超臨界水によって分別回収された粗骨材

によって $90 \%$ \%上のアスファルト分離率か得られた回収 後の粗骨材性状を比較評価した .なお , バインダーはス トレートアスファルト (St.As.60-80) を 6 号砕石に対して $2 \mathrm{wt} \%$ 被膜させた 。

\section{（1）回収粗骨材の形状および表面性状}

図-4,図-5は,アスファルト被膜の粗骨材表面と高温・ 高圧水によって分別回収された粗骨材表面を, 左から 5 倍, 50 倍, 500 倍に拡大撮影したものである.亜臨界水 または超臨界水によって分別回収された粗骨材に，アス ファルト被膜前の粗骨材との差異は見られず，新規状態 との識別か涃難なほど，形状および表面性状が十分に復 元されているのが分かる. また, 回収粗骨材の質量はア スファルト被膜前の新規状態と同等であることから，高 温・高圧水によって粗骨材の形質を保持したまま被膜ア スファルトとの分別回収か河能であると考えられる .

このことから，高温・高圧水によって分別回収された 粗骨材は, 機械破砕による細粒化やアスファルトの偏在 を生ずることなく，形状および表面性状か新規状態に極 めて近い状態に初期化されたと言える .

\section{（2）回収粗骨材の材質}

回収粗骨材の材質に関する評価として, 粗骨材の密度 およひ吸水率試験（JIS A 1110準拠）を実施した .

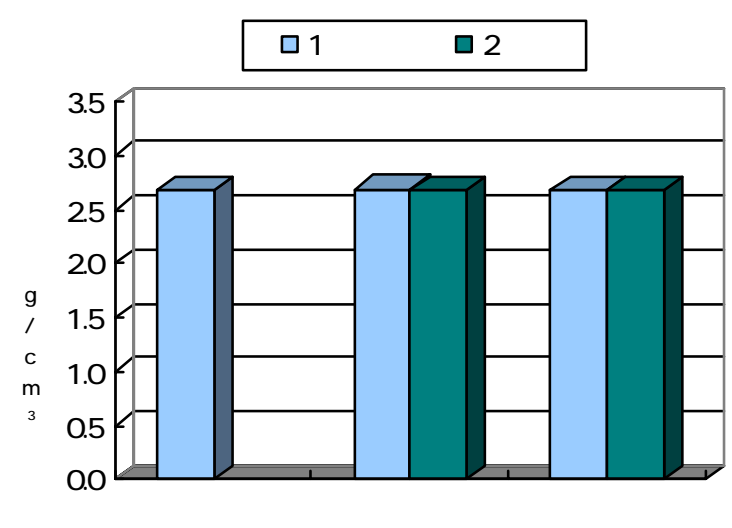

图-6 繰返し分別回収された粗骨材の密度

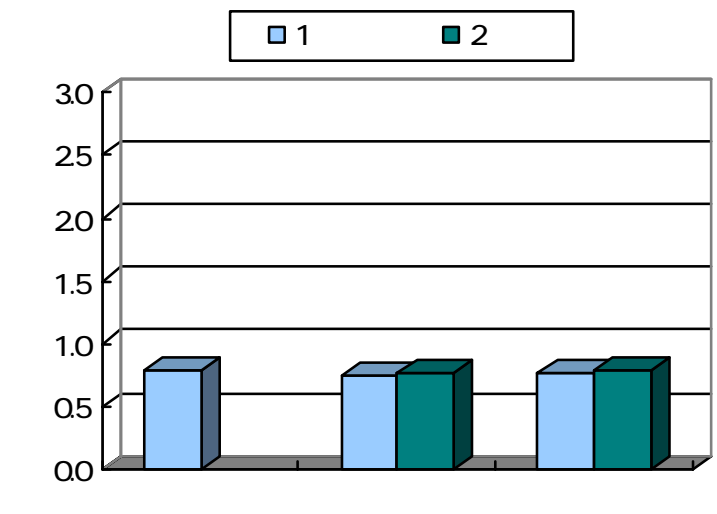

图-7 繰返し分別回収された粗骨材の吸水率

繰返し分別回収された粗骨材の密度を图 6 に示す. 亜 臨界水, 超臨界水ともに回収粗骨材の密度は, 新規粗骨 材と同程度であり，分別回収を繰り返すことによる密度 の変化は生じていない.なお, 回収粗骨材の密度は分別 1 回目, 2 回目ともに舗装用砕石の目標值である $2.5 \mathrm{~g} / \mathrm{cm}^{3}$ 以上を十分に満足している.

繰返し分別回収された粗骨材の吸水率を図-7に示す． 高温・高圧水によって回収された粗骨材は, 被膜アスフ アルトと分別されたことによって表面性状力溉ね初期化 し, 新規粗骨材と同等の吸水率力得られている.また， 繰返し分別回収を行うことによる吸水率への影響は見ら れず, 亜臨界水, 超臨界水回収後ともに目標値である $3.0 \%$ 以下を十分に満足している.

以上から，高温・高圧水によって繰返し分別回収され た粗骨材の材質は, 舗装用骨材の目標值を満足すること から, 新規粗骨材と同樣の取り扱いか河能であると考え られ，このことは舗装発生材の繰返し利用とともに，コ ンクリート資材等への用途拡大の可能性を示唆している.

\section{（3）回収粗骨材の耐久性}

回収粗骨材に対する耐久性の評価として，ロサンゼル ス試験機による粗骨材のすり減り試験 (JIS A 1121 準拠)， 硫酸ナトリウムによる安定性試験 (JIS A 1122準拠) を 実施した。 


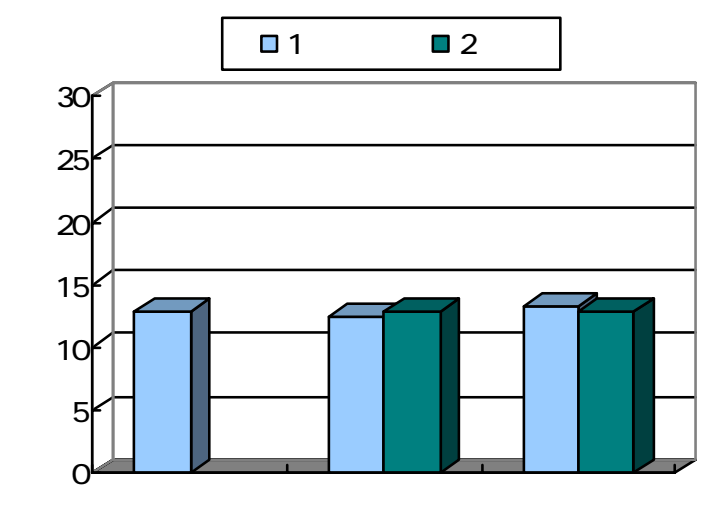

図-8 繰返し分別回収された粗骨材のすり減り減量

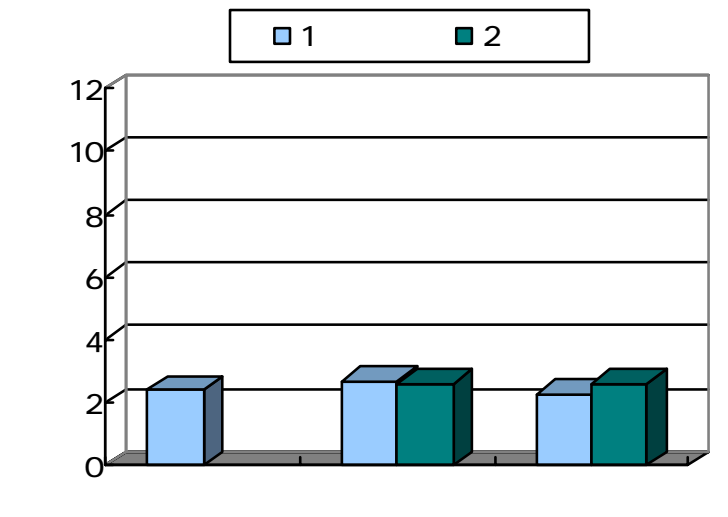

図-9 繰返し分別回収された粗骨材の損失質量百分率

高温・高圧水によって繰返し分別回収された粗骨材の すり減り減量を図 8 に示す. 亜臨界水, 超臨界水ともに 回収粗骨材のすり減り減量は, アスファルト被膜前と同 程度であり，分別回収を繰り返したことによるすり減り 抵抗性の差異は生じていない . なお，回収粗骨材のすり 減り減量は, 分別 1 回目, 2 回目ともに表層・基層用砕石 の目標值である $30 \%$ 以下を満足している.

繰返し分別回収された粗骨材の損失質量百分率を図 9 に示す. 高温・高圧水によって分別された粗骨材の損失 質量百分率は, 亜臨界水, 超臨界水回収後ともに新規粗 骨材と同程度であり，耐久性の目標值とされる $20 \%$ 以下 (上層路盤)， $12 \%$ 以下 (表層，基層) を満足している。 これらのことから，高温・高圧水によって分別回収さ れた粗骨材は，摩耗や破砕，凍結融解作用等に対する耐 久性を保持していることか確認され，分別回収による粗 骨材の持続的利用の可能性力認められた .

\section{4 . 回収細骨材に関する評価}

供試体は , 舗装設計施工指針 ${ }^{11}$ に規定されている密粒 度アスファルト混合物(最大粒径 $13 \mathrm{~mm}$ )の粒度範囲から， $2.36 \mathrm{~mm}$ 以下の粒度分布となるよう細骨材および石粉を配 合 (砕砂 $66.7 \%$ ，粗砂 $20.2 \%$ ，石粉 $13.1 \%$ ）した .なお， バインダーにはストレートアスファルト 60-80 を配合し

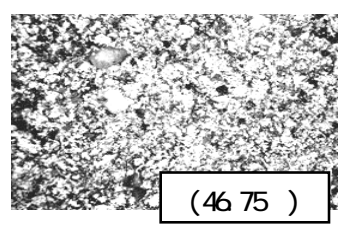

アスファルト混合前

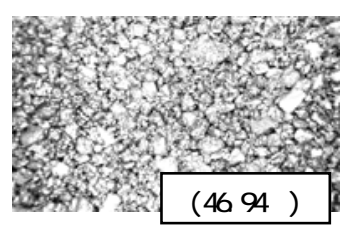

亜臨界水回収後

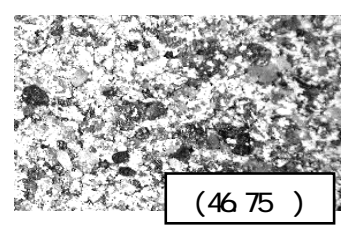

アスファルト混合前

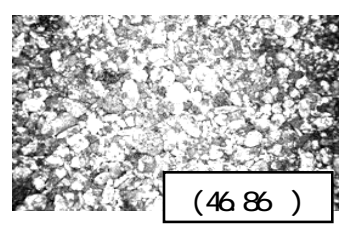

超臨界水回収後
図 10 アスファルト混合前および分別回収後の細骨材

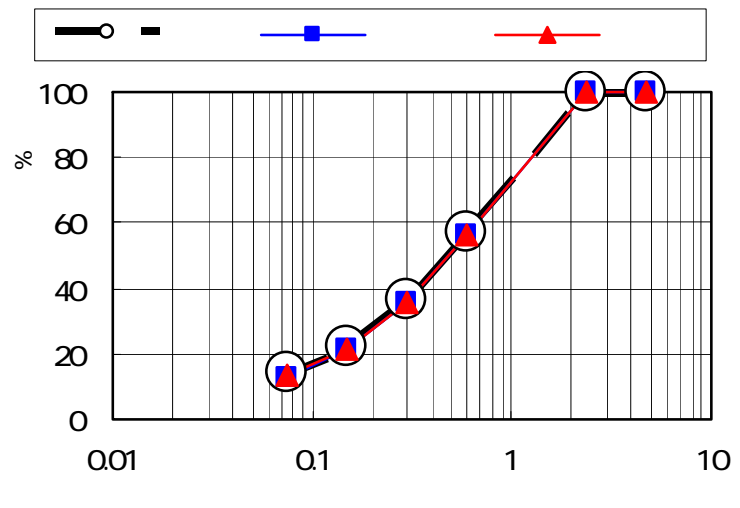

图-11 細骨材の配合粒度と回収試料粒度

た試料に対して 6wt％加熱混合して作製した 。

評価はアスファルトを混合していない新規の配合試料

(以下 , 混合前)を基準として , 亜臨界水 $\left(350^{\circ} \mathrm{C} \cdot 16.5 \mathrm{MPa}\right)$ または超臨界水 $\left(400^{\circ} \mathrm{C} \cdot 25.0 \mathrm{MPa}\right)$ によって分別回収さ れた試料 (以下, 回収後) を比較検討した。

\section{（1）回収細骨材の粒度}

回収細骨材の粒度評価として骨材のふるい分け試験 (JIS A 1102 準処) を実施した 。

アスファルト混合前の新規細骨材と亜臨界水およひ超 臨界水によって分別回収された細骨材を図-10に 細骨材 の配合粒度と回収試料の粒度を图 11 に示す . 亜臨界水， 超臨界水回収後の試料からは，目視による識別が十分に 可能なほど , 白色の石粉が混合前に近い状態て確認され た。また，回収された試料の質量および粒度に，アスフ アルト混合前との差異力生じていないことから，高温・ 高圧水によって細骨材の形状と粒度を保持したまま，加 熱混合したアスファルト分との厳密な分別回収か可能で あると考えられる .

このことは, 骨材の分別回収による分級の厳密化と， これに伴うより柔軟な再利用の可能性を示唆している.

\section{(2) 回収細骨材の材質}

回収細骨材の材質に関する評価として, 細骨材の密度 


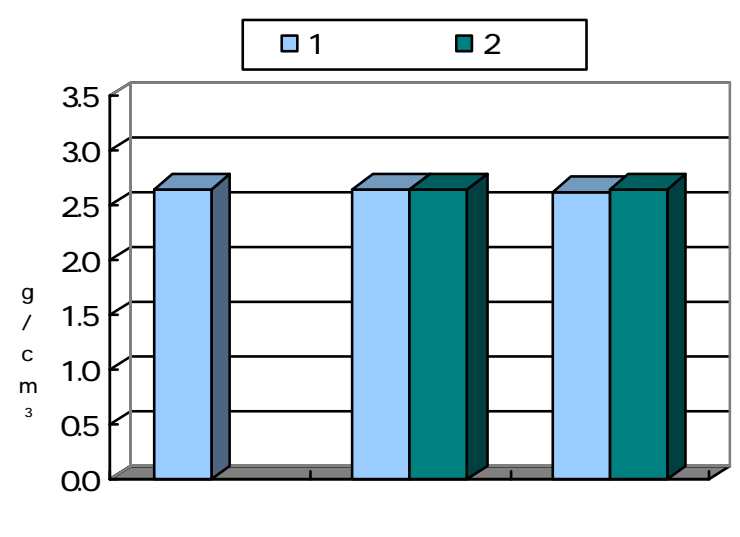

図-12 繰返し分別回収された細骨材の密度

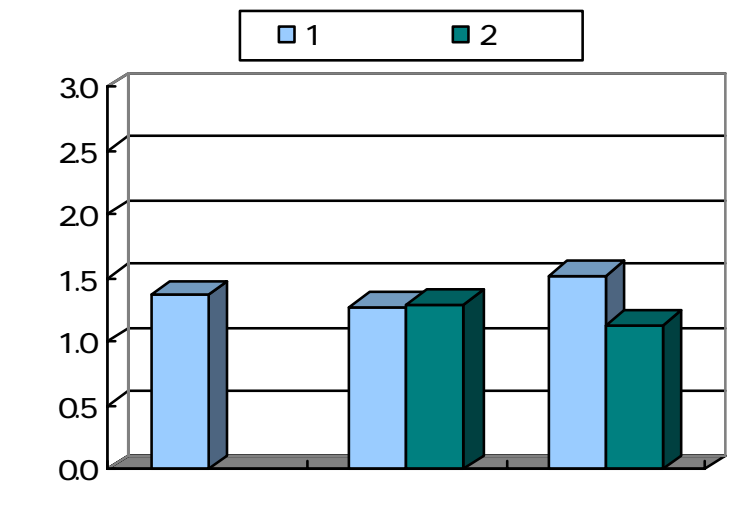

図-13 繰返し分別回収された細骨材の吸水率

およひ吸水率試験（JIS A 1109準拠）を実施した．

繰返し分別回収された細骨材の密度を图-12に示す．高 温・高圧水によって分別回収された細骨材の密度は, 亜 臨界水, 超臨界水回収後ともにアスファルト混合前と同 等である.また，繰返し分別回収を行うことによる密度 の変化は生じておらず, アスファルト混合前に対する回 収後の密度は平均值からの偏差が 0.01 以下であった 。

繰返し分別回収された細骨材の吸水率を図 13 に示す。 亜臨界水回収後の細骨材は, アスファルト混合前と同程 度の吸水率を有しており，光の偏差は $0.03 \%$ 以下の範囲 内である . 一方, 超臨界水回収後に関しては 1 回目と 2 回目の吸水率に差異が見られるものの，これらの偏差は

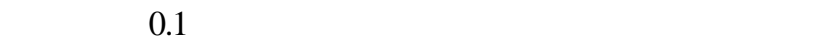
す程度ではな。

以上から , 亜臨界水または超臨界水によって分別回収 された細骨材は, アスファルト混合前とほほ同等の材質 を保持しており，新規骨材と同樣の品質管理と取扱いが 十分可能なものと考えられる .

\section{（3）回収細骨材の耐久性}

細骨材の硬さに関しては, 幾つかの機関て独自の評価 が行われているものの, 未だ確立された試験方法は示さ れていない現況にある ${ }^{12,13,14)}$. 本研究ては , 高温・高圧 水か細骨材の品質に与える影響を考慮して, ロータップ

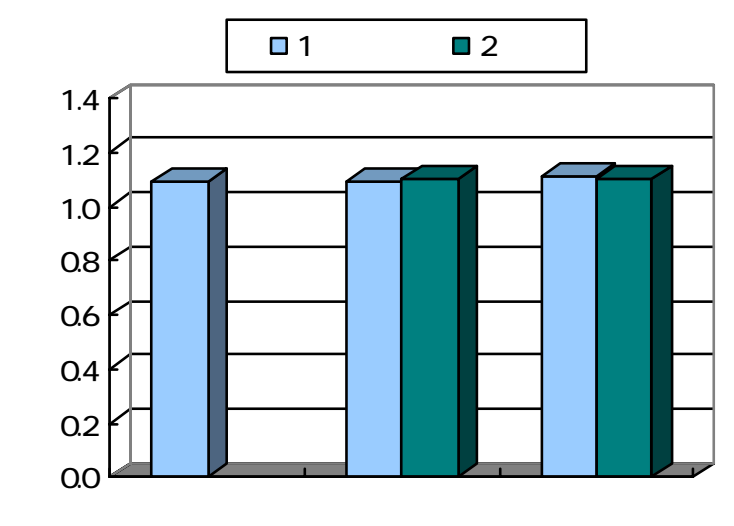

図 14 繰返し分別回収された細骨材の細粒化率

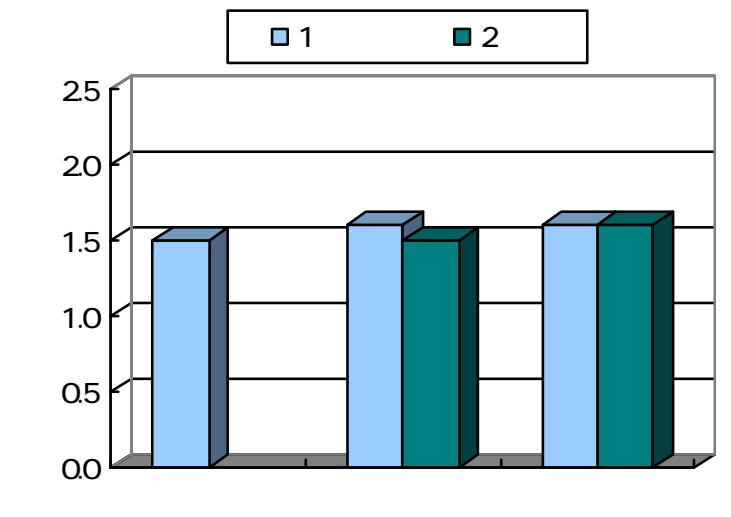

図-15 繰返し分別回収された細骨材の損失質量百分率

ふるい振とう機による細骨材のすり減り試験を実施し， 摩耗や破砕に対する耐久性を評価した . 試験は，500g の 試料を振とう機 (ふふるい目 : $2.36,1.20,0.60,0.30,0.075$ $\mathrm{mm})$ に入れ，0.6 mmふ、るい上に投入した鋼球 $(\varphi 25,67 \mathrm{~g}$, 20 個) とともに 30 分間振とうさせる.結果は,試験前後 における $0.6 \mathrm{~mm}$ 通過質量百分率の比 (試験後/試験前) を 求め, これを細粒化度として比較評価した . また，微細 なひひ割れや凍結融解作用に対する安定性およひ耐久性 に関する評価として，硫酸ナトリウムによる安定性試 験（JIS A 1122 準拠）を実施した 。

繰返し分別回収された細骨材の細粒化率を図-14に示 す. 高温・高圧水によって分別回収された細骨材は, 新 規細骨材と同程度の細粒化度であり，摩耗や破砕に対す る十分な耐久性力確忍された . なお，繰返し回収後の細 粒化度についても, 亜臨界水, 超臨界水回収後の細粒化 度に大きな差異は生じていないことから，アスファルト 混合前の品質を保持していると言える .

繰返し分別回収された細骨材の損失質量百分率を図 - 15 に示す. 高温・高圧水によって分別された細骨材の損 失質量百分率は, 覀臨界水, 超臨界水回收後ともに新規 粗骨材に比へて僅かに増加する傾向が見られる . しかし ながら 舗装用砕石の耐久性の目標值である $20 \%$ 以下(上 層路盤)，12\%以下 (表層, 基層) を参考とすると，耐久 性を左右するほどの大きな変化ではない . 
表-1 混合物の配合と物性値

\begin{tabular}{|c|c|c|c|c|c|c|}
\hline & \multirow{2}{*}{$\begin{array}{l}\text { 新100 } \\
77.0\end{array}$} & \multirow{2}{*}{$\begin{array}{l}\text { 再20 } \\
\text { 新 } 80 \\
66.0\end{array}$} & \multirow{2}{*}{$\begin{array}{l}\text { 再40 } \\
\text { 新60 } \\
55.0 \\
\end{array}$} & \multirow{2}{*}{$\begin{array}{c}\text { 回100 } \\
77.0\end{array}$} \\
\hline \multirow{6}{*}{\begin{tabular}{|c|} 
骨 \\
材 \\
配 \\
合 \\
比 \\
\% \\
\end{tabular}} & 6号不 & & & & & \\
\hline & 7号不 & & 11.0 & 8.0 & 5.0 & 11.0 \\
\hline & 砕 & & 7.0 & 2.0 & - & 7.0 \\
\hline & 粗 & & - & 一 & - & - \\
\hline & 再生骨木 & & - & 20.0 & 40.0 & - \\
\hline & 石 & & 5.0 & 4.0 & - & 5.0 \\
\hline \multirow{6}{*}{$\begin{array}{l}\text { 通 } \\
\text { 過 } \\
\text { 質 } \\
\text { 量 } \\
\text { 分 } \\
\text { 率 }\end{array}$} & 19.0 & & 100.0 & 100.0 & 100.0 & 100.0 \\
\hline & 13.2 & & 100.0 & 100.0 & 100.0 & 100.0 \\
\hline & 9.5 & & 70.0 & 71.3 & 72.6 & 70.0 \\
\hline & 4.75 & & 23.3 & 23.2 & 23.1 & 23.0 \\
\hline & 2.36 & & 12.0 & 12.2 & 12.3 & 12.0 \\
\hline & 0.60 & & 7.9 & 9.3 & 8.9 & 8.0 \\
\hline \multirow{3}{*}{ \% } & 0.30 & & 6.7 & 7.9 & 6.8 & 6.5 \\
\hline & 0.15 & & 5.7 & 6.1 & 4.0 & 5.5 \\
\hline & 0.07 & & 4.6 & 5.0 & 2.8 & 4.5 \\
\hline \multicolumn{2}{|c|}{ 設計アスファルト量 } & $\%)$ & 4.5 & 4.2 & 4.3 & 4.4 \\
\hline \multicolumn{2}{|c|}{\begin{tabular}{|l|} 
密度 \\
\end{tabular}} & $\left.\mathrm{g} / \mathrm{cm}^{3}\right)$ & 1.948 & 1.975 & 1.988 & 1.970 \\
\hline \multicolumn{2}{|c|}{ 空隙率 } & \%) & 21.9 & 20.1 & 20.4 & 21.9 \\
\hline \multicolumn{2}{|c|}{ 飽和度 } & $\%$ ) & 28.1 & 28.7 & 29.1 & 27.9 \\
\hline
\end{tabular}

表- 2 再生用添加斉の性状

\begin{tabular}{|c|c|c|c|c|}
\hline \multicolumn{3}{|c|}{ 試験項目 } & 試験方法 & 性状值 \\
\hline \multicolumn{2}{|c|}{ 動粘度 $60^{\circ} \mathrm{C}$ ) } & $\left(\mathrm{mm}^{2} / \mathrm{S}\right)$ & JIS K 2283 & 187.0 \\
\hline \multicolumn{2}{|l|}{ 引火点 } & iC) & JIS K 2265 & 254.0 \\
\hline \multicolumn{3}{|c|}{ 薄膜加熱後の動粘度比 $60^{\circ} \mathrm{C}$ ) } & JIS K 2207 & 1.3 \\
\hline \multicolumn{2}{|c|}{ 薄膜加熱質量変化率 } & $\%)$ & JIS K 2207 & -0.4 \\
\hline \multicolumn{2}{|l|}{ 密度 $15^{\circ} \mathrm{C}$ ) } & $\left.\$ / \mathrm{cm}^{3}\right)$ & JIS K 2249 & 1.0 \\
\hline \multirow{4}{*}{ 組成成分 } & アスファルテン & $\%)$ & 石油学会法 & 0.0 \\
\hline & 飽和分 & $\%)$ & 石油学会法 & 46.6 \\
\hline & 芳香族分 & $\%)$ & 石油学会法 & 48.2 \\
\hline & レジン & $\%)$ & 石油学会法 & 5.2 \\
\hline
\end{tabular}

これらのことから，高温・高圧水によって分別回収さ れた細骨材は, 新規状態の摩耗や破砕, 凍結融解作用等 に対する耐久性を保持していることか確認され，分別回 収による細骨材分の持続的利用の可能性力認められた .

\section{5 . 回収骨材のアスファルト混合物への再利用}

ポーラスアスファルト混合物の普及や老朽化を背景に， 舗装発生材のリサイクルに関する研究力漬極的に行われ ている ${ }^{3) \sim 8)}$.このことから，排水性舗装発生材から製造 される再生骨材は再生密粒度混合物に適用可能であるこ とか確忍されているが , 再生骨材のポーラスアスファル 卜混合物への利用については未だ骨材飛散抵抗性やひび 割れに関する課題と懸念を残している.本研究では，高 温・高圧水によって分別回収された骨材のポーラスアス ファルト混合物への再利用を検討するため, 新規混合物 と再生混合物を作製し, カンタブロ試験 (養生 : $20^{\circ} \mathrm{C}$, $-20^{\circ} \mathrm{C}$, 水浸 $60^{\circ} \mathrm{C}$ ) および圧裂試験 (養生 : $0^{\circ} \mathrm{C}, 60^{\circ} \mathrm{C}$ )

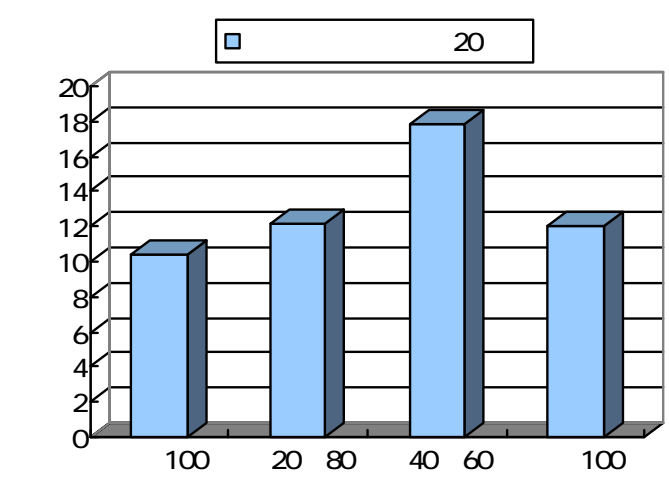

図 16 標準カンタブロ損失量 $\left(20^{\circ} \mathrm{C}\right)$

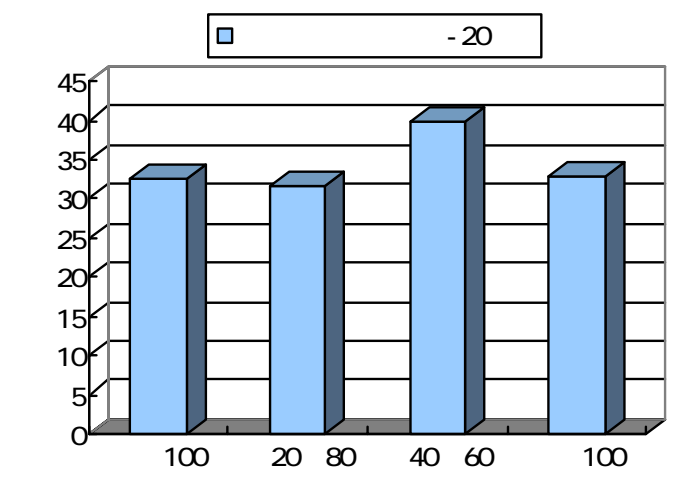

图 17 低温カンタブロ損失量 $\left(-20^{\circ} \mathrm{C}\right)$

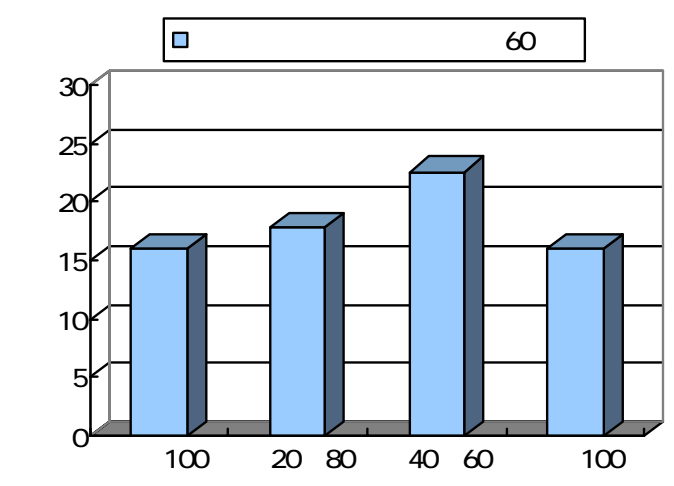

図 18 水浸カンタブロ損失量 (水温 $60^{\circ} \mathrm{C}$ )

から，回収骨材を配合した混合物を評価した．

混合物の配合と物性值を表-1に示す．供試体は，新規 骨材およびポリマー改質アスファルト $\mathrm{H}$ 型を用いたポー ラスアスファルト混合物 (以下, 新規 100) と, 密粒度混 合物から製造した再生骨材 (13〜 $0 \mathrm{~mm})$ を $20 \%$ および $40 \%$ 使用した再生ポーラスアスファルト混合物（以下，再 20 新 80 , 再 40 新 60) を比較試料として, 高温・高圧水

$\left(350^{\circ} \mathrm{C} \cdot 16.5 \mathrm{MPa}\right)$ によって密粒度舗装発生材から回収 した骨材を配合したポーラスアスファルト混合物（以下， 回収 100）を評価した.なお，再生混合物を作製する際に 使用した再生添加斉の性状は表- 2 に示すとおりである .

\section{（1）ポーラスアスファルト混合物の骨材飛散抵抗性}

標準カンタブロ損失量 $\left(20^{\circ} \mathrm{C}\right)$ を図 16 , 低温カンタブ 口損失量 $\left(-20^{\circ} \mathrm{C}\right)$ を図- 17 , 水浸カンタブロ損失量 (水 浸 $60^{\circ} \mathrm{C}$ ) を図 18 に示す. 既往方法によって作製した再 


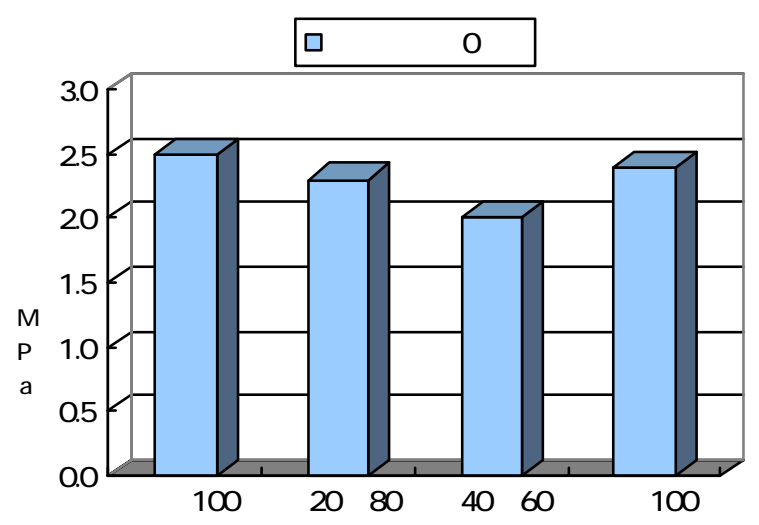

図- 19 圧裂強度 $\left(0^{\circ} \mathrm{C}\right)$

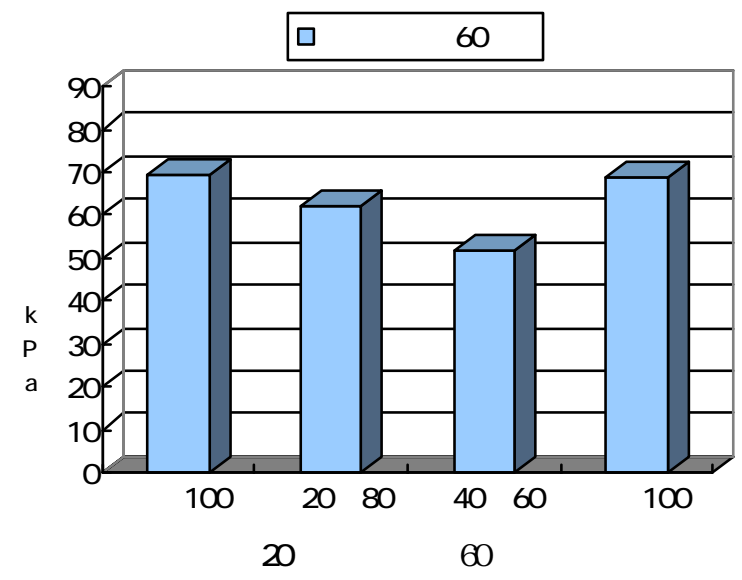

生混合物は, 再生骨材の混入率増加に伴って損失量力増 加し, 再生骨材を $40 \%$ 混入した再 40 新 60 の性能低下が 顕著である.一方, 回収骨材を $100 \%$ 用いた混合物は, 標 準, 低温, 水浸損失量ともに, 新規のポーラスアスファ ルト混合物と同等の性能力得られている .

このことは, 再生骨材に残存する旧アスファルトの性 状に起因したものと考えられるが, 発生材中の旧アスフ アルトについては種類を特定できない場合が多く，光の 劣化や変質の程度も異なることから, 再生用添加剂の適 否か困難なことを示唆している.しかしながら, アスフ アルトと骨材を分別回収することで, 再生用添加斉や新 規骨材に依存することなく , ポーラスアスファルト混合 物を製造することか可能であると考えられる .

\section{（2）ポーラスアスファルト混合物のひひ割れれ抵抗性}

$0^{\circ} \mathrm{C}$ おび $60^{\circ} \mathrm{C}$ における圧裂強度を图 19 ，図-20 に示 す . 再生ポーラスアスファルト混合物は, 再生骨材の混 入率増加に比例して圧裂強度が低下する傾向にあり，旧 アスファルトの勒性低下か発現している .一方, 回収骨 材のみで作製したポーラスアスファルト混合物の圧裂強 度は, $0^{\circ} \mathrm{C}, 60^{\circ} \mathrm{C}$ もに新規のポーラスアスファルト混合 物と同程度である。

以上から , アスファルト混合物の感温性や路面性状と

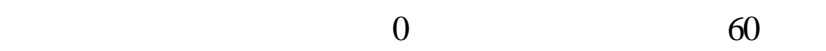
おける圧裂強度) に関しても ${ }^{14)}$ ，回収骨材によって作製
したポーラスアスファルト混合物は新規のものと同等で あることか確認され，再生ポーラスアスファルト混合物 の課題であるひひ割れ抵抗性に対する分別回収の有効性 か認如れた . 今後も，弚の他の岩種を対象とした検証 か不可欠であるが, 発生材中の骨材は岩石か不特定な場 合が多く,岩質の一樣化は困難と言える.しかしながら， 特定のリサイクルプラントに搬入される舗装発生材の発 生源地域は限られていること，すなわち，含有する骨材 の産地がある程度限定されることから，地域循環型社会 の構築に向けた具体的な検証力行えるものと考える.

\section{6.まとめ}

本研究では, 高温・高圧水を用いたアスファルト混合 物の分別プロセスを提案し, 繰返し回収された粗骨材お よび細骨材の性状と品質を評価した .

以下に得られた知見を取りまとめる .

a) 高温・高圧水によって分別回収された粗骨材および 細骨材は, 形状 , 材質, 耐久性ともにアスファル卜 を被膜する前の骨材と同等の性状を保持している．

b) 高温・高圧水によって繰返し分別回収された骨材は， 舗装用骨材の目標值を満足し, 新規骨材と同樣の取 り扱いか可能と考えられる。

c）回収骨材から作製したポーラスアスファルト混合物 は, 骨材飛散抵抗性, ひひ割れれ抵抗性ともに新規混 合物と同等の性能を有している .

以上の結果から、高温・高圧水によって繰返し分別回 収された粗骨材および細骨材は，概ねアスファルト被膜 前の初期状態に復元されていることから，新規材料に依 存することなく，付加価値の高い重交通路表層，更には 排水性舗装等への高度利用か可能であると考える．

高温・高圧水による分別プロセスの実用化については， 装置のスケールアップに伴う技術的または経済的な課題 を残している.今後，回収されたアスファルト分に関す る検討を重ね，回収資材の循環利用を前提とした，より 実用的な溶媒条件の検討を行う必要があると考えている． 謝辞 : 本研究は文部科学省の学術フロンティア推進事業 による私学助成を得て行われたものであり，ここに記し て謝意を表す。

\section{参考文献}

1）建設副産物リサイクル広報推進会議: 総合的建設副産物対 策 (平成 15 年度版)，2003。

2）(社)日本道路協会 : 舗装再生便覧， pp.1-2, pp.31, pp.206， pp.38, pp.14-21, pp.124, pp.215, 2004 .

3) 久利良夫, 佐野正典, 柳下文夫, 山田優 : 微粉末材料を活 用したアスファルト舗装発生材の再材料化に関する研究, 土木学会論文集，第627号，V-44，pp.27-36，1999.

4) 向後憲一, 加藤義輝 : 排水性アスファルト混合物の再生利 用技術に関する検討，土木学会舗装工学論文集，Vol.6， 
pp.94-99 , 2001 .

5）村山雅人, 菅野宏, 姫野賢治 : 排水性アスファルト混合物 の再生利用に有効な添加剂の検討，土木学会舗装工学論文 集 , Vol.7, pp.26-1-26-8，2002 .

6) 村山雅人, 菅野宏 , 川口洋 : 排水性アスファルト混合物の 再生利用に有効な改質添加斉の検討，舗装，Vol.39，No.2， pp.9-15, 2004 .

7) 新田弘之, 伊藤正秀 : 改質アスファルトのリサイクル技術 に関する検討，土木技術資料，Vol.46 ,No.1 pp.44-49,2004.

8) Yosuke Kano, Shoichi Akiba and Yuzo Kuriyagawa : Separation and Recovery of Aggregate from Asphalt Pavement Wastes Using High Temperature and High Pressure Water , JOURNAL OF THE JAPAN PETROLEUM INSTITUTE , Vol.49 , No.5 , pp.231-239 , 2006 .

9) Yosuke KANO , Shoichi AKIBA , Yuzo KURIYAGAWA and
Tadashi KAWAI : Removal of Binder from Asphalt Mixture Using High Temperature and High Pressure Water , JOURNAL OF THE JAPAN PETROLEUM INSTITUTE , Vol.48 , No.6 , pp.358-364 , 2005

10）加納陽輔, 秋葉正一, 栗谷川裕造 : 超臨界水を用いたアス ファルト抽出試験に関する基礎検討, 土木学会舗装工学論 文集，Vol.10，pp.249-256，2005。

11) (社)日本道路協会 : 舗装設計施工指針 (平成 18 年度版)， pp.221, 2007 .

12）飯島尚，小島逸平:アスファルト混合物用細骨材の試験法， 舗装，Vol.18，No.6，pp.3-10，1983．

13）井上武美 : 道路用細骨材の硬さ試験方法の提案, 土木学会 論文集，No.250，pp.133-136，1976。

14）(社)日本道路協会 : 舗装調査・試験法便覧, 第 2 分冊, pp.4-pp.110，第3 分冊, pp.78, 2007 .

\title{
QUALITY AND PERFORMANCE OF AGGREGATE SEPARATED FROM RECLAIMED ASPHALT PAVEMENT BY USING HIGH-TEMPERATURE AND HIGH-PRESSURE WATER
}

\begin{abstract}
Shoichi AKIBA, Yosuke KANO and Yuzo KURIYAGAWA
High-temperature and high-pressure water, which has solvent performance, is supercritical and subcritical water. This paper presents method to separate aggregate from asphalt mixture by using these water. Then, applying the method, the quality of separated aggregate was firstly evaluated by the several tests. And then, the performance of drainage asphalt mixture using it was evaluated by the several tests. As the results, it was confirmed that the subcritical water can remove the asphalt from asphalt mixture as same as the supercritical water, and separated fine aggregate and coarse aggregate were the same as the former quality. And, for the performance of the mixture, it was compared with the mixture that the waste material was mixed, and the result was confirmed that the performance is well.
\end{abstract}

